\title{
PERILAKU PENJUALAN ADAPTIF PENGARUHNYA TERHADAP KINERJA TENAGA PENJUALAN
}

\author{
Dewinta Muslikha Hidayati, Paulus Wardoyo ${ }^{\text {1), }}$, Endang Rusdianti ${ }^{2)}$ \\ 1) adyalk@gmail.com; ${ }^{2}$ erusdianti@usm.ac.id \\ Program Magister Manajemen Universitas Semarang
}

\begin{tabular}{l} 
Info Artikel \\
\hline Sejarah Artikel: \\
Diterima \\
Disetujui \\
Dipublikasikan \\
\hline Keywords: \\
customer \\
orientation;salesperson \\
teknical competence; adaptive \\
sales behavior; performance \\
of salespeople \\
\end{tabular}

\begin{abstract}
Abstrak
Penelitian ini bertujuan untuk menganalisis dan membuktikan secara empiris pengaruh dari orientasi pelanggan dan kompetensi teknik tenaga penjual terhadap perilaku penjualan adaptif. Serta pengaruh dari kompetensi teknik tenaga penjual dan perilaku penjualan adaptif terhadap kinerja tenaga penjual.

Penelitian ini menggunakan sample sebanyak 102 orang, sedangkan teknk sampling yang digunakan adalah sensus. Hasil penelitian ini membuktikan kompetensi teknik tenaga penjual tidak berpengaruh terhadap kinerja tenaga penjual dan perilaku penjualan adaptif berpengaruh terhadap kinerja tenaga penjual
\end{abstract}

\section{THE EFFECT OF ADAPTIVE SALES BEHAVIOR ON SALESFORCE PERFORMANCE}

\begin{tabular}{|c|c|}
\hline & Abstract \\
\hline & $\begin{array}{l}\text { The purpose of studies to analyze and prove empirically the influence } \\
\text { of customer orientation and the technical competence of salespeople } \\
\text { on adaptive sales behaviors. As well as the influence of the } \\
\text { salesperson's technical competence and adaptive sales } \\
\text { behavior in the performance of salespeople. } \\
\text { This study used a sample of } 102 \text { people, while the sampling technique } \\
\text { used was the census. The results of this study prove the competence } \\
\text { of salespeople techniques do not affect the performance of } \\
\text { salespeople and the sales behavior adaptive effect on the } \\
\text { performance of salespeople. }\end{array}$ \\
\hline Alamat korespondensi : & 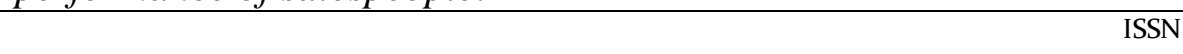 \\
\hline $\begin{array}{l}\text { Program Magister Manajeme } \\
\text { E-mail: adyalk@gmail.com; }\end{array}$ & $\begin{array}{l}\text { n Universitas Semarang } \\
\text { 2)erusdianti@usm.ac.id }\end{array}$ \\
\hline
\end{tabular}




\section{PENDAHULUAN}

Perusahaan yang bergerak dalam bidang penjualan produk, baik berupa barang ataupun jasa, tentunya akan memilih rangkaian bauran promosi yang tepat. Salah satunya adalah dengan mengaplikasikan personal selling. Hal ini berlaku baik bagi ranah Business to Consumer (B2C), ataupun ranah Business to Business (B2B). Sebagai salah satu dari bauran promosi, personal selling banyak digunakan oleh perusahaan yang menjual barang yaitu Personal selling menggunakan media sales force (tenaga penjual). Penyebab perusahaan memilih cara ini karena barang atau jasa yang ditawarkan tersebut membutuhkan cara menjual yang tidak umum dan tindakan pasca pembelian yang lebih intensif dibandingkan barang lain.

Terdapat isu dari penelitian terdahulu mengenai faktor yang dapat mempengaruhi kinerja tenaga penjual. Issue tersebut yaitu pengaruh dari orientasi pelanggan terhadap kinerja tenaga penjual. Chen, (2012) mengemukakan bahwa orientasi pelanggan adalah kepercayaan organisasi untuk menempatkan keuntungan pelanggan di tempat pertama untuk mengembangkan profitabilitas jangka panjang. Kelly (1992) dalam Chen, (2012) mengasumsikan bahwa peran orientasi pelanggan dalam industri jasa lebih penting dari pada industri lainnya, dan ini merupakan faktor penting dalam persepsi kualitas pelanggan.

Hasil penelitian yang dilakukan Varghese, (2015), Kavoosi,et al (2014) dan Chen, (2006) membuktikan bahwa orientasi pelanggan berpengaruh signifikan terhadap kinerja tenaga penjual. Berbeda hasil dengan penelitian yang dilakukan Rigdon, (2014) menjelaskan bahwa orientasi pelanggan tidak berpengaruh terhadap kinerja tenaga penjual.

Kinerja penjual mengacu pada prestasi finansial dan non finansial yang dicapai oleh tenaga penjual individu sehubungan dengan peran dan tanggung jawabnya sesuai dengan yang ditetapkan oleh perusahaan. Ini menunjukkan seberapa baik kinerja tenaga penjual menjalankan tugas penjualannya terkait saat melaksanakan tanggung jawab pekerjaan yang ditugaskan (Babakus, Cravens, Grant, Ingram, \& LaForge, 1996 dalam Wong, 2016). Penelitian yang dilakukan Wong, (2016) mendapatkan hasil bahwa perilaku adaptif berpengaruh signifkan dalam meningkatkan kinerja tenaga penjual.

Pemilihan variabel ini dengan alasan, kemampuan atau kinerja tenaga penjual dapat meningkat apabila seorang tenaga penjualan memiliki perilaku penjualan adaptif yang tinggi yaitu dengan menggunakan pendekatan penjualan yang berbeda secara tepat pada saat transaksi dengan pelanggan dan pada saat membuat keputusan selama transaksi penjualan berlangsung untuk situasi penjualan yang berbeda. Spiro dan Weitz (1990) dalam Kavoosi,et al (2014) mendefinisikan perilaku penjualan adaptif seperti yang terdiri dari mengumpulkan informasi tentang calon pelanggan, mengembangkan strategi penjualan, mengevaluasi dampak dari pesan ini, dan melakukan penyesuaian (dalam presentasi penjualan) berdasarkan evaluasi ini. Sebenarnya, perilaku penjualan adaptif adalah kemampuan penjual untuk memenuhi operasinya dengan kebutuhan bersama pembeli (Keillor dan Parker, 2000 dalam Kavoosi et al (2014).

Dalam rangka untuk memperkuat perilaku penjualan adaptif dari tenaga penjual, maka dapat disokong dengan kompetensi tenaga penjual (selling skill), semakin tinggi kompetensi dari tenaga penjual, maka semakin berkualitas perilaku penjualan adaptif dari tenaga penjual. Keahlian tenaga penjual merupakan pengetahuan khusus yang terkait dengan hubungan bisnis yang dimiliki dan 
kemampuan seorang tenaga penjual untuk memberikan solusi pada pelanggannya juga dapat menunjukkan tingkat keahlian tenaga penjualan tersebut (Liu \& Leach,2001 dalam Mulatsih, 2011 ). Hasil penelitian yang dilakukan Mulatsih, (2011) menjelaskan bahwa kompetensi teknik tenaga penjual dapat meningkatkan kinerja tenaga penjual. Begitu pula penelitian yang dilakukan Kavoosi, et al (2014) mendaapatkan hasil bahwa pengetahuan dari tenaga penjual dapat memoderasi (menguatkan) pengaruh perilaku penjualan adaptif terhadap kinerja tenaga penjual.

\section{TELAAH PUSTAKA DAN PENGEMBANGAN MODEL Kinerja Tenaga Penjual}

Kinerja tenaga penjual adalah suatu evaluasi dari kontribusi tenaga penjual untuk mencapai tujuan-tujuan organisasi (Baldauf, Cravens, dan Piercy, 2001). Pengertian kinerja tenaga penjual menurut Baldauf et al.,(2001), adalah sebuah evaluasi dari kontribusi tenaga penjual terhadap pencapaian tujuan organisasi. Sedangkan Hidayah (2001), mendifinisikan kinerja tenaga penjual sebagai sebagai penilaian terhadap perilaku dalam bekerja. Konsep kualitas perilaku ini merefleksikan aktivitas tenaga penjual yang menunjukan hasil yang berbedabeda.Bedasarkan paparan diatas dapat disimpulkan bahwa kinerja tenaga penjual adalah penilaian dalam bekerja serta bagaimana pemenuhan target oleh tenaga penjual. Pemenuhan target dapat menjadi cerminan bagaimana kontribusi dan tanggung jawab tenaga penjual terhadap perusahaan. Kemampuan tenaga penjual dalam mencapai target yang ditetapkan dan memberikan kontribusi merupakan hal penting yang harus dipertimbangkan dalam efektivitas organisasi penjualan.

Menurut Baldauf \& Cravens (2002), kinerja tenaga penjual ditentukan oleh perilaku tenaga penjual secara individual. Dengan demikian, kinerja tenaga penjual dapat dievaluasi dengan menggunakan faktor-faktor yang dapat dikendalikan oleh tenaga penjual itu sendiri dan dapat diukur melalui: Total volume penjualan: tingkat penjualan yang dihasilkan oleh tenaga penjualtersebut dalam periode tertentu; Pencapaian target penjualan: target penjualan yang ditentukan olehperusahaan atau tenaga penjual itu sendiri, serta bagaimana tenaga penjual mencapai target penjualan tersebut; Penjualan produk dengan profit margin tinggi: keuntungan tinggi yangdidapat dari penjualan; Menghasilkan porsi pasar tinggi: tenaga penjual dapat memberikan pangsapasar yang luas bagi produk yang ditawarkan; Menghasilkan tingkat penjualan yang tinggi: penjualan produk yang tinggi mampu menghasilkan keuntungan bagi perusahaan atau tenaga penjual tersebut. Merujuk Challagalla dan Shervani, (1996) indikator dari kinerja tenaga penjual adalah : kemampuan mencapai target penjualan, adanya tamabahan pesanan dan peningkatan prosentase penjualan.

\section{Perilaku Penjualan Adaptif}

Penjualan adaptif (adaptive selling) atau adaptasi dalam penjualan dapat didefinisikan sebagai perubahan perilaku penjualan selama interaksi pelanggan berdasarkan pada informasi yang berharga tentang sifat-sifat pejualan yang situasional(Spiro dan Weitz, 1990). Penjualan adaptif juga merupakan kemampuan untuk berkomunikasi secara efektif dengan pelanggan yang sangat penting bagi penjual (Boorom et. al, 1998). Menurut Boorom et. al. (1998) penjualan adaptif adalah kemampuan penjual untuk membuat dan memodifikasi pesan-pesan melalui komunikasi interaktif dengan pelanggan. Sujan (1999) juga menjelaskan penjualan adaptif sebagai kemampuan tenaga penjual untuk 
membuat pengamatan yang perseptif terhadap situasi penjulan dan memodifikasi responnya secara tepat. Spiro dan Weitz (1990) mendefinisikan penjualan adaptif sebagai suatu aktivitas mengubah perilaku penjualan selama ataupun setelah terjadinya interaksi dengan pelanggan, yang dilakukan berdasarkan pada informasi yang diterima mengenai situasi penjualan.

Seorang tenaga penjual dikatakan memiliki tingkat penjualan adaptif yang tinggi apabila dapat menggunakan pendekatan penjualan yang berbeda secara tepat pada saat transaksi dengan pelanggan dan pada saat membuat keputusan selama transaksi penjualan berlangsung untuk situasi penjualan yang berbeda. Sebaliknya tenaga penjual dikatakan memiliki tingkat penjualan adaptif yang rendah apabila mereka hanya menggunakan teknik pendekatan penjualan dan pengambilan keputusan penjualan yang sama untuk seluruh transaksi penjualan yang dilakukannya dalam bentuk situasi penjualan apapun (Farida, 2005).

Sejalan dengan pendapat tersebut, Indriani (2005) juga menyatakan bahwa seorang tenaga penjual dikatakan memiliki tingkat adaptivitas tenaga penjualyang tinggi apabila dapat menggunakan pendekatan penjualan yang berbeda secara tepat pada saat transaksi dengan pelanggan dan saat membuat keputusan selama transaksi penjualan berlangsung disaat situasi penjualan yang berbeda. Sebaliknya, tenaga penjual dikatakan memiliki tingkat adaptivitas tenaga penjual yang rendah, apabila mereka hanya menggunakan teknik pendekatan dan pengambilan keputusan penjualan yang sama untuk seluruh transaksi yang dilakukan dalam situasi penjualan apapun.

Kemampuan tenagapenjual untukmenggunakanpendekatan penjualan yang berbeda sesuai dengan situasi penjualan yang dihadapai serta jenis pelanggan yang ditemui. Menurut Indriani (2005) indikator perilaku penjualan adaptif meliputi : kemampuanmenggunakan teknik penjualan dengan pelanggan; kemampuan melakukan negosiasi; Memiliki sekumpulan informasi mengenai situasi penjualan yangberbeda.

\section{Kompetensi Teknik Tenaga Penjual}

Menurut Baldauf dan Cravens (2002) kemampuan teknik mengacu pada perilaku tenaga penjual dalam menyediakan informasi tentang fitur dan spesifikasi produk sertapenggunaan dan fungsi produk dan jasa. Sementara itu Rentz et al.,(2002) keahlian teknik menjual adalah pengetahuan yang dimiliki tenaga penjual dalam rangka mendukung penjualannya, seperti misalnya pengetahuan mengenai desain dan keistimewaan produk (menguasai product knowledge), pengetahuan tentang pemakaian dan fungsi produk, pengetahuan tentang teknik (keahlian engineering) dan prosedur yang diberlakukan oleh kebijakan perusahaan.Aspek keahlian tenaga penjual dalam aktivitas penjualan sebagai sebuahatribut dari tenaga penjual. Hal ini berarti bahwa baik tidaknya kinerja seorangtenaga penjual terletak pada kemampuan seorang tenaga penjual dalammenjalankan aktivitas penjualan secara efektif.

Sujan, et al., (1994) menyatakan bahwa orientasi pada keahlian tenaga penjual dalam aktivitas penjualan akan menyebabkan kinerja tenaga penjual diharapkan berkembang cepat, sesuai dengan harapan yang ingin dicapai. Keahlian menjual sering juga ditunjukkan dengankemampuan tenaga penjual untuk memberikan solusi yang dibutuhkan olehpelanggannya, sehingga pelanggan merasakan adanya nilai tambah yang diperoleh.Kemampuan menjual yang dimiliki tenaga penjual akan semakin meningkat,peningkatan ini terjadi seiring pembelajaran seorang tenaga penjual terhadap kondisi yang dihadapi didalam melaksanakan tugas penjualannya. Keahlian menjual juga digambarkan sebagai 
sebuah orientasi dari seseorang untuk berusaha melakukanperbaikan dan meningkatkan kemampuan serta penguasaan atas pekerjaan yangmenjadi tanggungjawabnya. Arafat(2013), menyatakan bahwa keahlian dapat mempermudah dan membentuk sebuah pemahaman serta implementasi atas hubungan strategis antara perusahaandengan konsumennya.

Dalam penelitian yang dilakukan oleh Ahmad (2010) terdapat beberapaindikator dalam pengukuran technical skill tenaga penjual, sebagai berikut: pengetahuan produk : pengetahuan mengenai spesifikasi, fungsi danpenggunaan produk; pengetahuan pelanggan : pengetahuan mengenai apa yang dinginkan dandibutuhkan konsumen serta mampu memberikan solusi atau saran bagikonsumen; pengetahuan pesaing : pengetahuan mengenai produk dan layanan yangdigunakan pesaing serta strategi yang diterapkan oleh pesaing.

\section{Orientasi Pelanggan}

Konsep orientasi pelanggan juga dapat diartikan sebagai pemahaman yang menandai pelanggan yang ditargetkan oleh seorang penjual yang mampu menciptakan nilai kemanfaatan terbaik terus-menerus untuk barang yang dibeli pembeli tersebut atau, menurut (Narver 1990), untuk menciptakan "produk yang disukai pembeli"terus-menerus.Pemahaman disini mencakup pemahaman terhadap seluruh rantai nilai pembeli baik pada saat terkini maupun pada saat perkembangannya dimasa yang akan datang. Upaya ini dapat dicapai melalui proses pencarian informasi tentang pelanggan (Ucles, 2000). Dengan adanya informasi tersebut maka tenaga penjual pada suatu perusahaan akan memahami siapa saja pelanggan potensialnya, baik pada saat ini maupun pada masa yang akan datang. Dari penjelasan tersebut maka dapat dipahami bahwa penerapan orientasi pasar memerlukan kemampuan perusahaan dalam mencari berbagai informasi pasar sehingga dapat dijadikan dasar bagi perusahaan untuk melakukan langkah atau strategi selanjutnya.

Perusahaan yang berorientasi pada kepuasan pelanggan (customer satisfaction orientation) umumnya menggambarkan sebuah perilaku yang lebih responsif terhadap pelanggannya dengan memberi pelayanan purna jual, respon yang cepat terhadap keluhan pelanggan dan komitmen terhadap janji perusahaan kepada pelanggannya (Never dan Slater, 1994).

\section{Hubungan Logis Antar Variabel dan Pengembangan Model Pengaruh Orientasi Pelanggan Terhadap Perilaku Penjualan Adaptif}

Konsep orientasi pelanggan juga dapat diartikan sebagai pemahaman yang menandai pelanggan yang ditargetkan oleh seorang tenaga penjual yang mampu menciptakan nilai kemanfaatan terbaik terus-menerus untuk barang yang dibeli pembeli tersebut atau, menurut (Narver 1990), untuk menciptakan "produk yang disukai pembeli"terus-menerus. Pemahaman disini mencakup pemahaman terhadap seluruh rantai nilai pembeli baik pada saat terkini maupun pada saat perkembangannya dimasa yang akan datang. Upaya ini dapat dicapai melalui proses pencarian informasi tentang pelanggan (Ucles, 2000). Dengan adanya informasi tersebut maka perusahaan penjual akan memahami siapa saja pelanggan potensialnya, baik pada saat ini maupun pada masa yang akan datang.

Penelitian yang dilakukan Kharisma, (2015) membuktikan bahwa orientasi pelanggan berpengaruh terhadap perilaku penjualan adaptif.Berbeda hasil dengan penelitian yang dilakukan Novitasari, (2016) bahwa orientasi pelanggan berpengaruh terhadap perilaku penjualan adaptif.

Dari uraian diatas, maka hiptesis dalam penelitian ini yaitu : 
$\mathrm{H}_{1}$ : Semakin tinggi orientasi pelanggan yang dimiliki oleh tenaga penjualan, perilaku penjualan adaptifnya akan semakin tinggi

\section{Pengaruh Kompetensi Tenaga Penjual (Selling Skill) Terhadap Perilaku Penjualan Adaptif}

Menurut Ahmad (2010) kompetensi teknik tenaga penjual (technical sales skill) merupakan salah satu keterampilan yang dimiliki tenaga penjual dalam rangka mendukung kegiatan penjualannya, keterampilan teknis misalnya seperti pengetahuan mengenai informasi desain dan spesifikasi dari produk, kemudian aplikasi dan fungsi dari produk yang ditawarkan kepada pelanggan (penguasaan product knowledge). Pengetahuan tentang prosedur yang diberlakukan oleh perusahaan. Adanya keterampilan teknik, tenaga penjual mampu memberikan pelayanan yang memuaskan dan mampu meyakinkan pelanggan untuk membeli produk yang ditawarkan.

Penelitian yang dilakukan Kharisma, (2015) membuktikan bahwa kompetensi tenaga penjual (selling skill) berpengaruh terhadap perilaku penjualan adaptif. Berbeda hasil dengan penelitian yang dilakukan Hidayat, (2013) bahwa kompetensi tenaga penjual tidak berpengaruh terhadap perilaku penjualan adaptif. Dari uraian di atas, maka hipotesis dalam penelitian ini yaitu :

$\mathrm{H}_{2}$ : Semakin tinggi kompetensi teknik menjual dari tenaga penjual, perilaku penjualan adaptifnya semakin tinggi

\section{Pengaruh Kompetensi Teknik Tenaga Penjual (Selling Skill) Terhadap Kinerja Tenaga Penjual}

Menurut Rentz et al.,(2002) Technical Sales Skill (keahlian teknik), adalah pengetahuan yang dimiliki tenaga penjualan dalam rangka mendukung penjualannya, seperti misalnya pengetahuan mengenai desain dan keistimewaan produk (menguasai product knowledge), pengetahuan tentang pemakaian dan fungsi produk, pengetahuan tentang teknik (keahlian engineering) dan prosedur yang diberlakukan oleh kebijakan perusahaan.

Penelitian yang dilakukan Mulatsih, (2011) dan Kharisma, (2015) membuktikan bahwa kompetensi tenaga penjual (selling skill) berpengaruh terhadap kinerja tenaga penjual. Berbeda hasil dengan penelitian yang dilakukan Cristiana, (2014) bahwa kompetensi tenaga penjual tidak berpengaruh terhadap kinerja tenaga penjual. Dari uraian di atas, maka hipotesis penelitian ini yaitu:

$\mathrm{H}_{3}$ : Semakin tinggi kompetensi teknik menjual dari tenaga penjual (selling skill), kinerja tenaga penjual semakin tinggi

\section{Pengaruh Perilaku Penjualan Adaptif Terhadap Kinerja Tenaga Penjual}

Bensi (2004) berpendapat bahwa tenaga penjual yang sukses adalah mereka yang dapat mengadaptasikan gaya komunikasinya secara tepat dalam interaksi dengan konsumen. Melalui teknik ini tenaga penjual dapat mengamati bagaimana reaksi dari konsumen terhadap strategi penjualannya dan melakukan penyesuaian seperlunya (Manske, et al., 2005).

Penelitian yang dilakukan Kavoosi, (2014), Lestari, (2015) dan Wong, (2016) membuktikan bahwa perilaku penjualan adaptif berpengaruh terhadap kinerja tenaga penjual. Berbeda hasil dengan penelitian yang dilakukan Cristiana, (2014) bahwa perilaku penjualan adaptif tidak berpengaruh terhadap kinerja tenaga penjual. Dari uraian di atas, maka hipotesis dalam penelitian ini yaitu :

$\mathrm{H}_{4}$ : Semakin tinggi perilaku penjualan adaptif dari tenaga penjual, kinerjanya akan semakin tinggi 


\section{Model Penilitian}

Berdasarkan telaah pustaka yang telah dilakukan, maka model penelitian disajikan dalam gambar berikut:

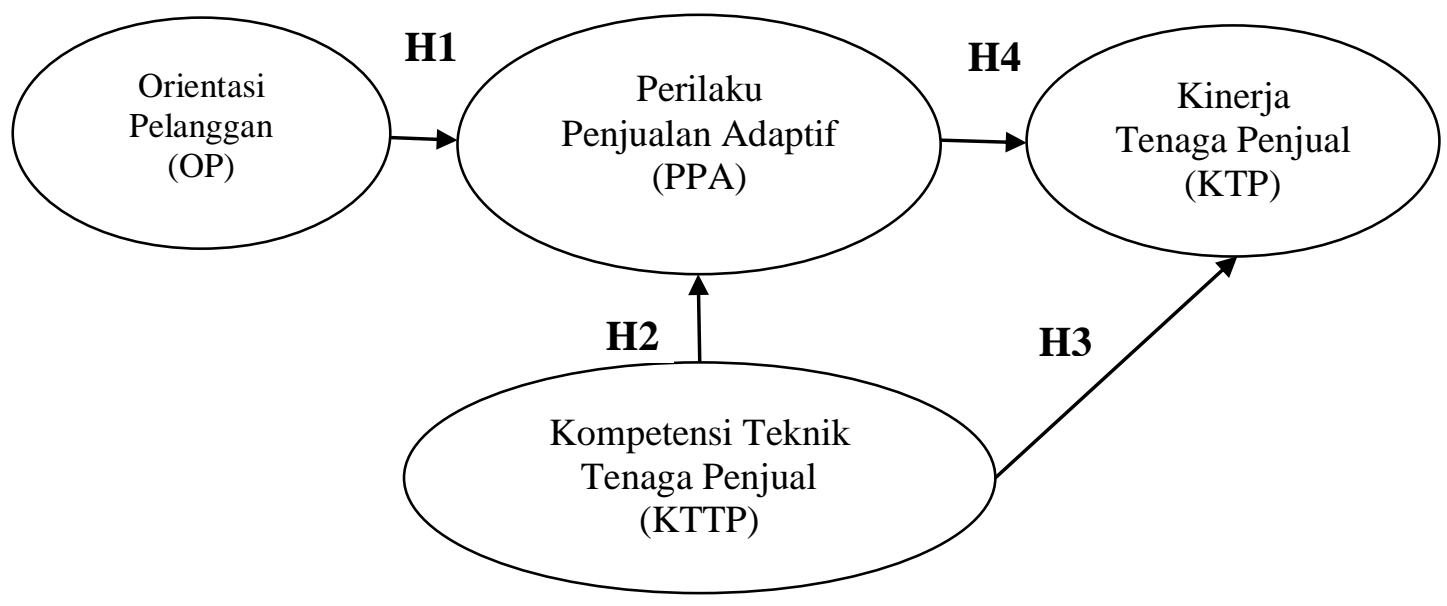

\section{Gambar 1 Model Penelitian}

\section{METODE PENELITIAN}

Populasi dalam penelitian ini adalah seluruh tenaga penjual di PT Pelabuhan Indonesia III (Persero), yang berjumlah 102 pegawai baik tetap maupun outsourcing Teknik sampling yang digunakan dalam penelitian ini adalah sensus. Pengolahan data dilakukan dengan bantuan software Lisrel 9.3 student version. Data yang digunakan berupa data primer yang diperoleh dengan memakai kuesioner yang diberikan kepada responden.

\section{ANALISIS DATA DAN PEMBAHASAN \\ Model Jalur}

Model analisis jalur yang telah dilakukan dengan LISREL diperoleh nilai koefisien jalur model standardized dan nilai t hitung. Dari hasil pengujian tersebut dapat ditulis persamaan sebagai berikut :

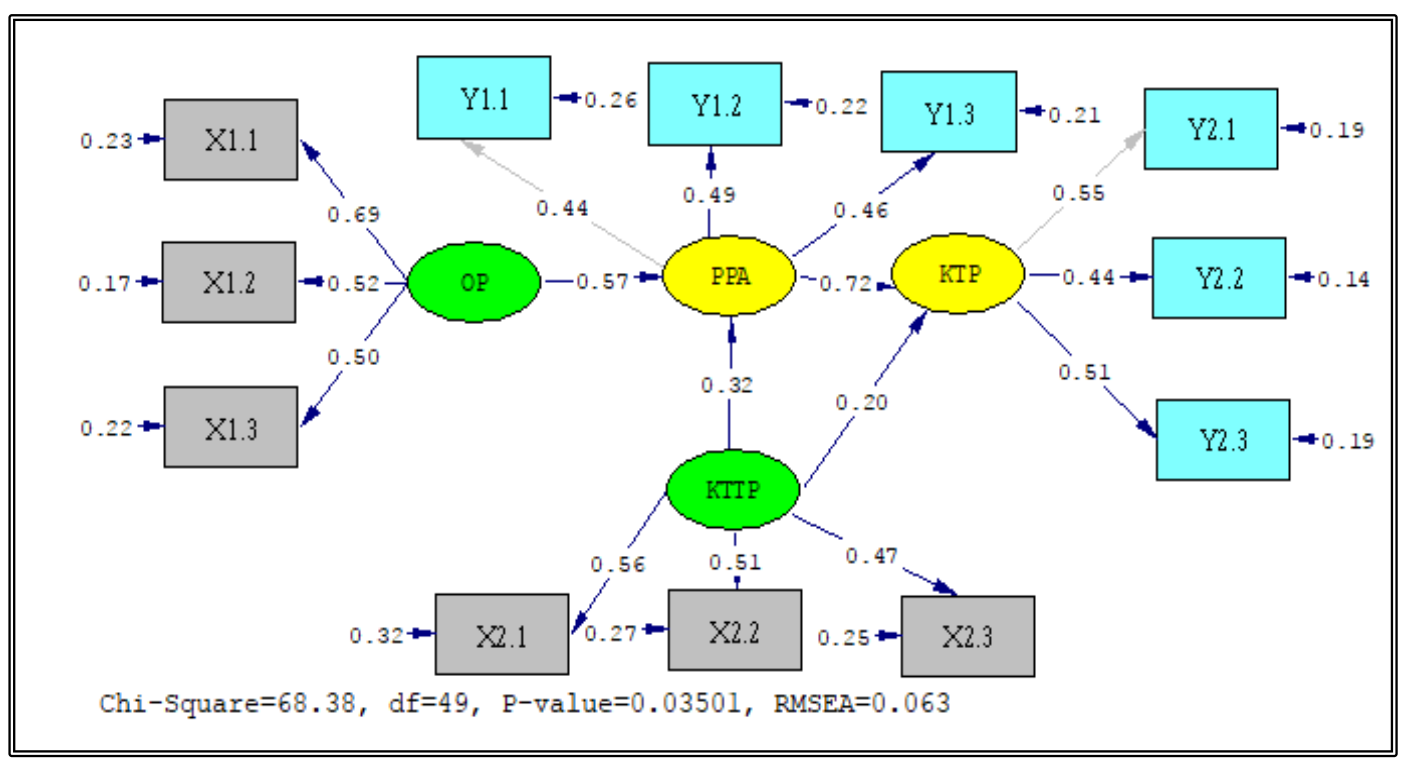

Gambar 2 Uji Signifikansi - Standardized Estimates 


\section{Structural Equations :}

$\mathrm{KTP}=0.72 * \mathrm{PPA}+0.20 * \mathrm{KTTP}$, Errorvar $=0.26, \mathrm{R}^{2}=0.74$

$\mathrm{PPA}=0.32 * \mathrm{KTTP}+0.57 * \mathrm{OP}$, Errorvar. $=0.38, \mathrm{R}^{2}=0.62$

\section{Pengaruh Langsung :}

PPA $=0.57 \mathrm{OP}+0.32 \mathrm{KTTP}$

$\mathrm{KTP}=0.72 \mathrm{PPA}+0.20 \mathrm{KTTP}$

\section{Pengaruh Tidak Langsung :}

$\mathrm{KTP}=(0.57 \mathrm{OP} * 0.72 \mathrm{PPA}) \mathrm{OP}+(0.32 \mathrm{KTTP} * 0.72 \mathrm{PPA}) \mathrm{KTTP}$

$$
=0.42 \mathrm{OP}+0.43 \mathrm{KTTP}
$$

\section{Total Pengaruh :}

$$
\begin{aligned}
\mathrm{KTP} & =0.72+(0.57 \mathrm{OP} * 0.72 \mathrm{PPA}) \mathrm{OP}+0.32(0.32 \mathrm{KTTP} * 0.72 \mathrm{PPA}) \mathrm{KTTP} \\
& =(0.72+0.42 \mathrm{OP})+(0.32+0.43 \mathrm{KTTP}) \\
& =1.14 \mathrm{OP}+0.75 \mathrm{KTTP}
\end{aligned}
$$

\section{Pengujian Hipotesis}

Untuk pengujian hipotesis untuk mengetahui pengaruh variabel bebas terhadap variabel terikat sebagai berikut

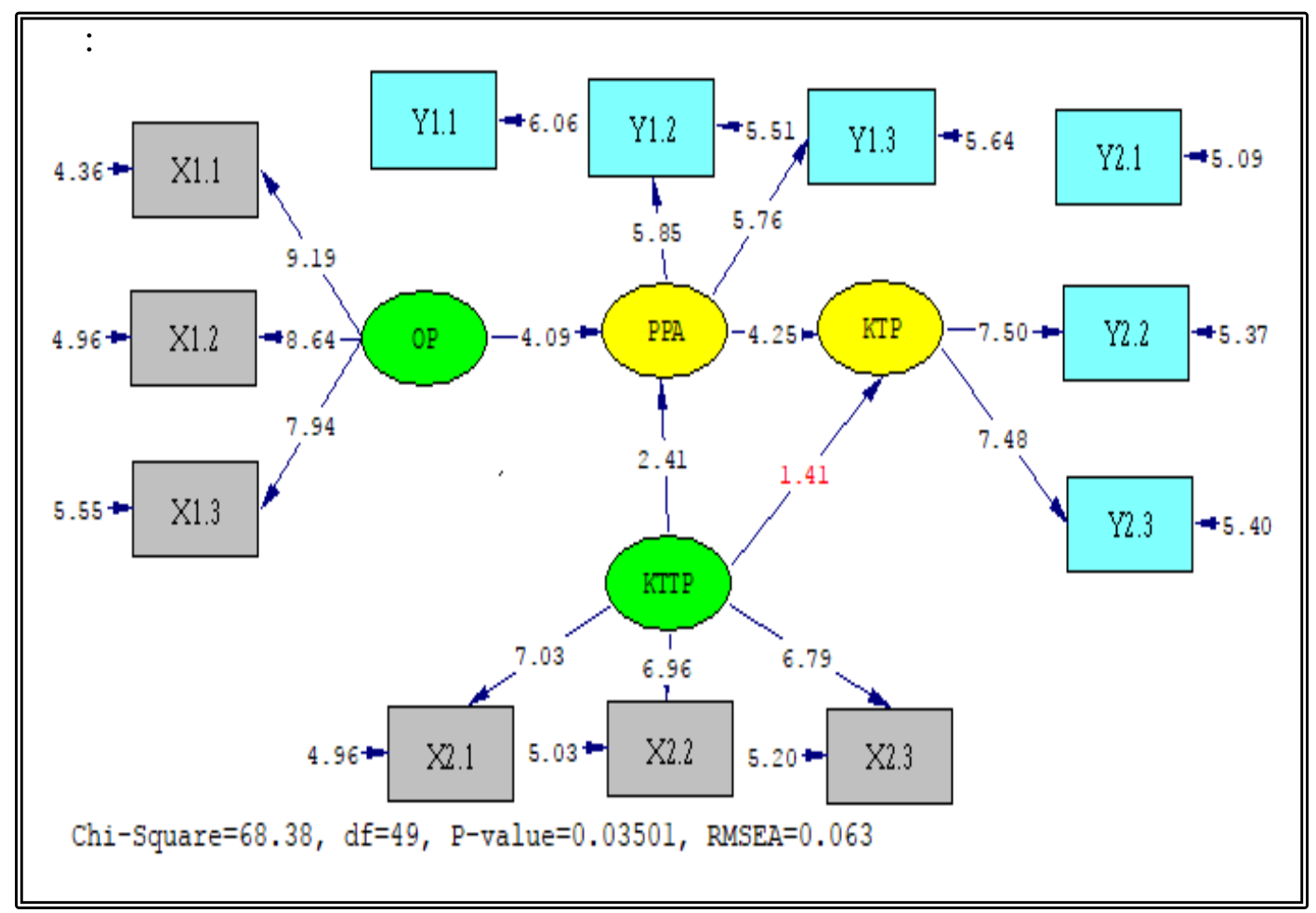

Gambar 3 Uji Signifikansi - Model T-Value 
Tabel 1 Pengujian Hipotesis

\begin{tabular}{|l|c|c|c|c|}
\hline Hipotesis & $\begin{array}{c}\text { T } \\
\text { Statistik }\end{array}$ & $>$ & T Value & Keterangan \\
\hline $\begin{array}{l}\text { Semakin tinggi orientasi pelanggan } \\
\text { yang dimiliki oleh tenaga penjualan, } \\
\text { perilaku penjualan adaptifnya akan } \\
\text { semakin tinggi }\end{array}$ & $\mathbf{4 . 0 9}$ & $>$ & $\mathbf{1 . 9 6}$ & Diterima \\
\hline $\begin{array}{l}\text { Semakin tinggi kompetensi teknik } \\
\text { menjual dari tenaga penjual, } \\
\text { perilaku penjualan adaptifnya } \\
\text { semakin tinggi }\end{array}$ & $\mathbf{2 . 4 1}$ & $>$ & $\mathbf{1 . 9 6}$ & Diterima \\
\hline $\begin{array}{l}\text { Semakin tinggi kompetensi teknik } \\
\text { menjual dari tenaga penjual (selling } \\
\text { skill), kinerja tenaga penjual semakin } \\
\text { tinggi }\end{array}$ & $\mathbf{1 . 4 1}$ & $>$ & $\mathbf{1 . 9 6}$ & Ditolak \\
\hline $\begin{array}{l}\text { Semakin tinggi perilaku penjualan } \\
\text { adaptif dari tenaga penjual, } \\
\text { kinerjanya akan semakin tinggi }\end{array}$ & $\mathbf{4 . 2 5}$ & $>$ & $\mathbf{1 . 9 6}$ & Diteria \\
\hline
\end{tabular}

Sumber : data yang diolah, 2017

\section{Pengaruh Orientasi Pelanggan Terhadap Perilaku Penjualan Adaptif}

Berdasarkan pengujian hipotesis menunjukkan jika nilai t value sebesar 4.09 > 1.96, hal ini menunjukkan bahwa orientasi pelanggan berpengaruh signifikan terhadap perilaku penjualan adaptif yang artinya hipotesis diterima.

\section{Pengaruh Kompetensi Teknik Tenaga Penjual Terhadap Perilaku Penjualan Adaptif}

Berdasarkan pengujian hipotesis menunjukkan jika nilai t value sebesar $2.41>$ 1.96, hal ini menunjukkan bahwakompetensi teknik tenaga penjual berpengaruh signifikan terhadap perilaku penjualan adaptif yang artinya hipotesis diterima.

\section{Pengaruh Kompetensi Teknik Tenaga Penjual Terhadap Kinerja Tenaga Penjual}

Berdasarkan pengujian hipotesis menunjukkan jika nilai t value sebesar $1.41<$ 1.96,hal ini menunjukkan bahwa kompetensi teknik tenaga penjual tidak berpengaruh signifikan terhadap kinerja tenaga penjual yang artinya hipotesis ditolak.

\section{Pengaruh Perilaku Penjualan Adaptif Terhadap Kinerja Tenaga Penjual}

Berdasarkan pengujian hipotesis menunjukkan jika nilai t value sebesar $4.25>$ 1.96, hal ini menunjukkan bahwaperilaku penjualan adaptifberpengaruh signifikan terhadap kinerja tenaga penjual yang artinya hipotesis diterima.

\section{KelayakanModel (Goodness of Fit Test)}

Uji goodness of fit testdigunakan untuk melakukan pengujian kemaknaan model dalam menjelaskan hubungan antar variabel sebagaimana yang dihipotesiskan. Berikut adalah hasil uji goodness of fit test : 
Goodness of Fit Statistics

$\begin{array}{ll}\text { Degrees of Freedom } & =49 \\ \text { Minimum Fit Function Chi-Square } & =71.98(\mathrm{P}=0.018) \\ \text { Normal Theory Weighted Least Squares Chi-Square } & =68.38(\mathrm{P}=0.035) \\ \text { Estimated Non-centrality Parameter }(N C P) & =19.38 \\ 90 \text { Percent Confidence Interval for NCP } & =(1.51 ; 45.27)\end{array}$

Berdasarkan hasil uji goodness of fit test didapatkan nilai chi square sebesar 71.98 dengan tingkat signifikansi $0,018<0,05$. Nilai estimasi NCP pada model sebesar 19.38 dan nilai confidence interval nya adalah $1.51 ; 45.27$. Nilai tersebut termasuk nilai kecil sehingga dapat diartikan model berada pada katagori cukup baik.

\section{PEMBAHASAN}

\section{Pengaruh Orientasi Pelanggan Terhadap Perilaku Penjualan Adaptif}

Hasil penelitian ini membuktikan secara empiris bahwa orientasi pelanggan berpengaruh signifikan terhadap perilaku penjualan adaptif. Konsep orientasi pelanggan juga dapat diartikan sebagai pemahaman yang menandai pelanggan yang ditargetkan oleh seorang penjual yang mampu menciptakan nilai kemanfaatan terbaik terus-menerus untuk barang yang dibeli pembeli tersebut. Hasil studi ini sejalan dengan hasil studi yang dilakukan oleh Kharisma (2015), Narver (1990) dan Ucles (2000)

\section{Pengaruh Kompetensi Teknik Tenaga Penjual Terhadap Perilaku Penjualan Adaptif}

Hasil penelitian ini membuktikan secara empiris bahwa kompetensi teknik tenaga penjual berpengaruh signifikan terhadap perilaku penjualan adaptif. Keterampilan tenaga penjual mampu memberikan pelayanan yang memuaskan dan mampu meyakinkan pelanggan untuk membeli produk yang ditawarkan. Hasil studi ini memiliki kesamaan dengan studi yang dilakukan Kharisma (2015)

\section{Pengaruh Kompetensi Teknik Tenaga Penjual Terhadap Kinerja Tenaga Penjual}

Hasil penelitian ini membuktikan secara empiris bahwa kompetensi teknik tenaga penjual tidak berpengaruh signifikan terhadap kinerja tenaga penjual. Dari hasil wawancara diketahui bahwa perusahaan tidak begitu memperhatikan kompetensi teknik dari masing-masing tenaga penjual karena pekerjaan tenaga penjual cenderung memiliki tingkat resiko yang lebih rendah, sehingga perusahaan ini lebih banyak menggunakan tenaga muda yang masih fress graduate Hasil studi ini cenderung memperkuat hasil penelitian yang dilakukan oleh Cristiana (2014).

\section{Pengaruh Perilaku Penjualan Adaptif Terhadap Kinerja Tenaga Penjual}

Hasil penelitian ini membuktikan secara empiris bahwa perilaku penjualan adaptif berpengaruh signifikan terhadap kinerja tenaga penjual. Tenaga penjual akan memberikan suatu teknik pemuasan kebutuhan kepada pelanggan karena mampu untuk mengenali setiap kebutuhan dan keinginan pelanggan yang berbeda-beda dan memberikan suatu alternatif pendekatan penjualan yang tepat untuk masing-masing situasi tersebut. Hasil studi ini memperkuat pendapat dari Bensi (2004); Manske et al (2005), Kavoosi (2014), Lestari (2015) dan Wong (2016) 


\section{PENUTUP}

Dalam rangka menjawab masalah penelitian yang telah dibahas sebelumnya mengenai pengaruh orientasi pelanggan dan kompetensi teknik tenaga penjual terhadap perilaku penjualan adaptif, serta pengaruh dari kompetensi teknik tenaga penjual dan perilaku penjualan adaptif terhadap kinerja tenaga penjual, maka dapat disimpulkan studi ini telah gagal membuktikan tentang pengarus kompetensi teknis menjual terhadap kinerja tenaga penjual Namun demkian studi ini mempunyai implikasi bahwa orientasi pelanggan dapat dilakukan dengan cara seoptimal mungkin memenuhi apa yang dibutuhkan pelanggan dengan tetap memperhatikan system dan prosedur, tenaga penjual perlu melengkapi diri dengan encari informasi sebanyak mungkin terkait dengan pelanggan dan pesaing agar produk yang ditawarkan dapat sesuai dengan kebutuhan pelanggan dan pelanggan berpikir ulang jika akan berpindah kepada produk pesaing. Kemudian untuk meningkatkan kompetensi teknik menjual, tenaga penjual perlu memiliki pemahaman detail tentang produk yang ditawarkan; teknik tenaga penjual lebih menitik beratkan kepada komunikasi, dimana dari komunikasi yang baik dan tepat maka pelanggan akan lebih mudah memahami produk yang ditawarkan. Selain itu tenaga penjual harus memiliki kemampuan beradaptasi dalam menghadapi pelanggan yang satu dengan yang lainnya karena pelanggan akan merasa lebih dihargai, serta memudahkan pelanggan dalam mengambil keputusan

\section{DAFTAR PUSTAKA}

Ahmad, B. M. S \& Kitchen, P. J. 2010.The Relationship Between Sales Skil And Salesperson Performance And The Impact Of Organizational Commitment As Amoderator: An Empirical Study In A Malaysian Tellecomunications Company. International Journal Of Economic And Management.

Arafat, R. 2013. Pengaruh Dimensi Sales Skill Terhadap Kinerja Penjualan. Management Analysis Journal 2 (1)

Cristiana. 2014. Pengaruh Kompetensi Tenaga Penjual, Penjualan Adaptif, Kepuasan Kerja Dan Motivasi Kerja Terhadap Kinerja Tenaga Penjual Dengan Variabel Mediasi Komitmen Organisasi.

Ferdinand Augusty. 2014, Metode Penelitian Manajemen Pedoman Penelitian untuk Penulisan Skripsi, Tesis, dan Disertasi Ilmu Manajemen, Edisi 3, AGF Books, Fakultas Ekonomika dan Bisnis Universitas Diponegoro, Semarang.

Ghozali, Imam. 2011. Aplikasi Analisis Multivariate dengan Program IBM SPSS 19. Semarang: UNDIP.

Kharisma, Meiga; Ibnu Widiyanto. 2015. Anteseden Penjualan Adaptif Dan Pengaruhnya Terhadap Kinerja Tenaga Penjualan. Diponegoro Journal Of Management, Volume 4, Nomor 4, Halaman 1-13, ISSN (Online) : 2337-3792.

Kavoosi, Sara Samaneh Sadeghian dan Kolsum Mahmudi. 2014. An Empirical Investigation Of The Impact Of Customer Orientation, Adaptive Selling Behaviors, And Job Satisfaction On Salespeople's Performance: The Moderating Role Of Selling Experience. International Journal of Research in Management, ISSN 2249-5908, Issue 4, Vol. 3 (May).

Lestari, Puji dan Sri Wartini. 2015. Pengaruh Technical Sales Skill Dan Non Technical Sales Skill Terhadap Kinerja Tenaga Penjualan Melalui 
Kepercayaan Konsumen Sebagai Variabel Intervening.Management Analysis Jornal, 4 (1), ISSN 2252-6552.

Mulatsih, Retno. 2011. Studi Tentang Kinerja Tenaga Penjualan (Study of Performance of Sales Persons) Kasus Empiris Pada PT. Sinar Niaga Sejahtera Area Distribusi Jawa Tengah I. Fokus Ekonomi, Vol. 6, No. 1, Juni : 19-39.

Novitasari. 2016. Dampak Orientasi Pasar : Orientasi Pesaing, Orientasi Konsumen Dan Koordinasi Lintas Fungsi Terhadap Perilaku Penjualan Adaptif Dan Kinerja Pemasaran.

Rigdon, Edward E \& Thomas G. Brashear. 2014. Customer Orientation And Salesperson Performance. Europan Journal of Marketing, Vol. 41, No. 7/8, pp. 821-835.

Wahyudi, Hidayat. 2013. Analisis Technical Sales Skill Dan Non Technical Sales Skill Terhadap Kinerja Tenaga Penjualan Melalui perilaku penjualan adaptif Sebagai Variabel Intervening (studi kasus pada Account Officer di BPR Restu Artha Makmur, Semarang).

Wong, Kok-Leong; Cheng-Ling Tan. 2016. Influence Of Supervisory Control On Salesperson Performance: Examining The Role Of Adaptive Selling Behaviour As A Mediator. Asian Academy of Management Journal, Vol. 21, No. 2, 183-203.

Varghese, Jose; Manoj Edward. 2015. Perceived Organizational Influences on Customer Orientation and Sales Performance - A Financial Services Industry Perspective. Journal of Marketing and Management, 6 (2), 11-21 